REPORT ON THE BLACKFRIARS SALVATION ARMY SHELTER PROSECUTION.* BY

F. J. WaLdo, M.A., M.D. Cantab, M.O.H. of St. George the Martyr, Southwark.

THE Vestry may be congratulated upon the fact that a danger to the common safety, although not altogether abolished, has nevertheless been brought nearer a proper sanitary control. In this way the Vestry of St. George the Martyr has carried out a public-spirited policy which deserves the thanks of every local authority in London.

The history of the facts which led up to the Blackfriars prosecution is simple.

For three years past I have called attention, in my annual reports, to the dangers arising from the presence of these over-crowded and ill-regulated pseudo-charities in your midst. The dangers in question may be divided under two heads, according to their injurious effect.

(Ist) Directly on inmates of the shelter.

(znd) Indirectly, on the outside public.

Copies of the reports dealing with these points have been duly laid before the Local Government Board and the London County Council. In $x 893$ the Government sent Dr. Airy to inspect the Metropolitan Night Shelters, but his report has not been made public, neither has the Local Government Board, so far as I know in my official capacity, taken any further steps in the matter, nor has the London County Council interfered. This was the position of affairs in the summer of the present year ( 1895 ), when an outbreak of small-pox occurred in your parish, and out of forty-fourcases no less than nine were traced directly to the Sheiter. I thereupon applied one nigbt at the Shelter for admission, which was refused, and I then drew the attention of the Committee to the occurrence. I was next instructed by your Committee to apply to the local magistrate for a warrant to enter the Shelter on the night of the 8th July. As a result of that visit your Committee obtained a summons asking for prohibition against future over-crowding. After a protracted hearing, extending over four months, the magistrate (Mr. Slade) granted the order asked for, and stated that, personally, he would not regard the presence of anything under 550 inmates as overcrowding. It is worthy of note that, despite the strong assertions of defendant's counsel in the course of the trial, no appeal has been made against the decision of the magistrate.

It may be well to add a few remarks upon the scientific evidence furnished in Court. The chemist who acted for your Vestry found 75 parts of carbonic-acid gas per 10,000 of air, in what was known as the "two-penny overflow bunk-room," whereas the usual limit regarded by sanitary officers as permissible is 6 parts of carbonic acid per 10,000. The chemist for the defence (Mr. Wanklyn) stated the figure 75 per 10,000 was impossible.

\footnotetext{
* From a Special Report of Dr. Waldo.
}

Without entering at length into the matter, I may say that Mr. Wanklyn's view runs counter to all standard scientific teaching and experience. Pettenkofer, for instance, one of the greatest living authorities on the subject, found $73^{*} 2$ parts per ro,000 in a girls' school. Mr. Wanklyn tested the air in the "two-penny overflow bunk room," and found 8.6 carbonic acid per 10,000. His figure 8.6 offers a startling contrast from our own figure of 75 . It is easily explained, however, by the facts that Mr. Wanklyn took his sample at an earlier hour of the night, and that between our visit of the 8th July and his experiment, extensive alterations had been carried out in the ventilation of the particular room in question.

This dispute between the chemists is unfortunate, because it tends to draw attention away from the main issue. It is entirely unnecessary, moreover, for I am prepared to state from the evidence of my own senses, apart from any chemical examination, that the air of the "two-penny overflow bunk room " on the night of July 8th was not only dangerous to health, but also to life itself. In this view I am supported by Dr. Walsh, who was with me on the night of the visit. Besides, a foul condition of the air followed, as a necessary result, from the gross over-crowding and the defective ventilation of the place. I may add that not a single medical officer of health could be found to give evidence for Mr. Booth in favour of the sanitary condition of the Shelter. On the other hand, my contentions as to unwholesomeness were supported by no less than five Metropolitan medical officers of health, to say nothing of independent medical and scientific testimony. According to my estimate, the Blackfriars Shelter was able to accommodate $40 x$ persons. On the night of entry I found $z, 03 x$. On two other occasions, on the admission of the Shelter officials, the numbers varied from 743 to $\mathbf{x}, 045$. When the magistrate, therefore, placed the limit at $55^{\circ}$, he convicted the Blackfriars Shelter authorities of gross overcrowding.

As regards the decision of Mr. Slade, I may say that, in my opinion, the Vestry is not bound to accept the figure of 550 , in the absence of any knowledge upon what basis that number has been fixed. At the same time it would, of course, be unwise to adopt any other standard in any possible future proceedings.

For my own part, I see no reason why the Vestry should lessen the reasonable demand for 30 square feet floor space, and 300 cubic feet air space for each inmate. This is the minimum I regard as necessary in the presence, I need hardly add, of free ventilation.

The weak point in the present position appears to be in the fact that your officers have no right of entry at night for purposes of inspection. As a matter of fact, I myself was refused admission in June last, and even when armed with a Justice's warrant I obtained an entrance only in the face of 
forcible resistance, and under the threat of bringing up a strong force of police.

In conclusion, it may be confidently expected that the action of your Vestry will sooner or later bring these shelters, and other night refuges of a similar nature, within the control of the Common Lodging Houses Act.

\section{THE EFFLUENT FROM SULPHATE OF AMMONIA WORKS.}

$\mathrm{BY}$

C. R. Macdonal.D, M.D., D.P.H., M.O.H. of the County of Ayr.

KILBrRnie Loch, like Castlesemple Loch in Renfrewshire, forms part of the remains of one great lake, which formerly stretched for six miles from Kilbirnie Station to Castlesemple.* The chief inlet of Kilbirnie Loch is the Maich Water, and its outlet the Dubbs, the latter flowing into Castle. semple Loch. Both the Maich and Dubbs join Kilbirnie Loch at its north end. At its south end the heap of slag from the Glengarnock Iron Works is constantly encroaching on the loch. Recently, chemical works for the manufacture of sulphate of ammonia have been erected near the edge of the loch on the Beith side of the iron works. The process in the manufacture of the ammonia is analogous to that in use in the manufacture of ordinary coal gas. The vapours from the blast furnaces are condensed into a liquor containing gas, tar, and ammonia. After the gas and tar are removed from the ammoniacal liquor the ammonia is separated by being passed into saturators containing sulphuric acid. The waste or spent liquor remaining after the separation of the gas, tar, and ammonia is the chief cause of the pollution in question. The first attempt at the disposal of this waste liquor was by conveying it in an iron pipe across the loch and pumping it up to the top of the slag hill. As this liquor cannot be rendered innocuous by filtration, it is evident that it would slowly percolate through the slag heap, and ultimately find its way into the loch. But though cattle watered in the loch were said to be injured by the water, the pollution was not clearly demonstrated until the wholesale poisoning of the fish occurred in the loch and in its outlet, the Dubbs, on the gth to the irth of March, x895. The poisoning of the fish was probably due to the fact that during the long spell of frost immediately preceding this date little or none of the waste liquor from the slag hill would get away, as it would freeze before it could percolate any distance; so that when the thaw set in on the gth of March the whole of this accumulation of the waste liquor would pass into the loch en masse, with the result referred to. About the same time the horses at

* Memoirs of the Geological Survey of Scotland, by Arch. Geikie, Edinburgh : Printed by Murray \& Gibb, I872. the Glasgow and South-Western Railway Station at Beith would not drink the water from the Dubbs stream, which was their usual water supply.

Since the date of the poisoning of the fish, the greater part of the waste liquor is said to be evaporated in the boilers. But analyses of samples of the loch water show that some at least of the chemical refuse is still finding its way into it. It may be stated that the soil near the edge of the loch, in the neighbourhood of the chemical works, seems saturated in some places with the chemical products, so that a certain amount of pollution of the water would occur from this source, even although none of the waste liquor would be discharged into it. The best method of getting rid of the waste liquor from ammonia works is to evaporate it in a Porion Evaporator, as is being carried out at the Dalmellington Iron Co.'s Ammonia Works on the river Doon.

\section{ANNOTATIONS.}

\section{Cerrification of Causes of Death.}

Or the $\mathrm{r}, 800$ deaths registered in Plymouth during I 895, I,688 or 93.8 per cent. were duly certified by registered medical practitioners, and Io 7 or $5^{\circ} 9$ per cent, by coroners after inquest, whilst the remaining 5 or $0^{\prime} 2$ per cent. were not certified.

Of the $x, 800$ deaths that occurred during 1895 in Plymouth, five only were uncertified. This decrease in the number of uncertified deaths is gratifying to note. During the year $\mathrm{r} 894$, sixteen deaths were uncertified either by coroner or medical practitioner; in this respect we compare most favourably with other large towns, and with the country generally. The number of uncertified deaths registered in England and Wales during 1895 was 13,222 , equal to a percentage of $2^{*} 3$ as against 0.2 per cent. in the Borough.

Any system of registration that permits of upwards of 13,000 uncertified deaths being registered during one year, is obviously faulty and. dangerous, leaving a loop-hole for the escape of the criminal, especially in a country in which the pernicious system of infantile insurance prevails. The most potent and only logical argument used against the practice of cremation is the destruction of all traces of the crime in certain cases of homicide; as long as the present system of death registration obtains, this argument loses force. Under the system adopted by the Cremation Society it is impossible to register any uncertified death, a system that should be, in the interest of humanity, adopted by the legislature.

It is evident from a perusal of the first and second reports of the Select Committee appointed to inquire into the sufficiency of the existing law in regard to death certification and disposal of the dead, that there is a concensus of opinion that the present system is faulty and that the law requires 